Gluckman gives a complete list of them; they include lion and leopard skins, eland tails, parts cut from the unskinned carcass of a hippopotamus. People could not keep or use a single ' kingly thing' without special permission. If a man killed an eland and did not take the tail to the king he would be punished-for eland tails were the great prerogative of kingship. If a hunter killed an elephant, he was bound to take both tusks to the king who kept the right tusk and gave the left back to the hunter. The killer of a lion brought the skin and received ten hoes; the killer of a leopard got five hoes in return for the skin. People were under no compulsion to hunt these animals in order to provide zabulena. Tribute was given back to the people in some form; zabulena remained with the king or were distributed only to special persons; the rewards he gave came from the tribute goods. Dr. Gluckman appositely compares the prerogative right of the English Crown to all white wild unmarked swans and in whales and sturgeon which are taken in the seas 'forming parcel of the dominions of the Crown'.

A further distinction must be drawn between namba, zabulena, and limpho. Limpho are ' gifts' freely offered to the king without any compulsion; thus many people bring him some of the fish from their first catch.

In I 906 Lewanika, the Paramount Chief (king), proclaimed the freedom of all slaves but reserved the right to call up men to labour unpaid for twelve days in a year. In 1925 Yeta III agreed to surrender the right to free labour in return for an annual sum of $£ 2,500$. A clause of his proclamation also abolished namba. The Paramount Chief continued to send out councillors to collect various things which he required; but people were no longer compelled to render them as tribute but were paid for them: a cash transaction took the place of an enforced levy.

An important legal question arises out of the 1925 proclamation. It formally abolishes namba, 'tribute', and says nothing about zabulena. Probably the British Government in agreeing to compensate the Paramount Chief and councillors for the loss of their dues intended that they should no longer receive any goods or labour (except elephant tusks) for which they did not pay cash. The Government, says Dr. Gluckman, did not then know the distinction between yamba and zabulena; but it is hardly open to doubt that it was present to the mind of the Paramount Chief and that he did not intend to give up his right to zabulena. "Whether legally, in view of the different connotations of the word " tribute" in the minds of the two parties, the Paramount can be held to have given up his rights to kingly things under the agreement, is a question for a lawyer, not a sociologist', Dr. Gluckman writes. 'But on the basis of the distinction which I have set out above, the Provincial Administration in Barotseland has now granted the Paramount's claim to half of the hides of all hippo killed in the Province.' Our only concern here is the extent to which other African peoples discriminate between 'tribute' and 'kingly things'. It may be observed that namba is not a Sotho word as zabulena is. Does this indicate that zabulena were imposed by the Sotho-speaking Makololo conquerers in addition to the namba already paid by the Luyi whom they subdued?

\title{
Personal
}

Ar its meeting on 24 October the Bureau received, and most regretfully accepted, the resignation of Dr. J. H. Oldham. We have not the space to write adequately at present of Dr. Oldham's services; it must suffice to say now that, apart from its technical side, the Institute owes more to him than to any other single man.

Professor C. Daryll Forde has been appointed to the chair of Anthropology at University College, London, but will continue to serve the Institute as Director. He thus returns to the College where he was first a student and later a junior member of the staff. His earliest field-studies were carried on for two years in America, among the Yuma of the Lower 
Colorado and the Hopi of Arizona. In 1930 he was appointed Gregynog professor of Geography and Anthropology in the University of Wales. In 1935 and 1939, as a Leverhulme Research Fellow, he investigated the social and economic life of the Yakö on the Cross River in Nigeria. His published work includes Habitat, Economy and Society, Marriage and the Family among the Yakö, and many papers. Amid other activities, he has been engaged on a general study of the native economies of Nigeria to be published shortly by Nuffield College. In his new appointment he carries the good wishes of the Bureau and of his colleagues at the Institute.

That remarkable linguist, Major R. C. Abraham, now retired from the Nigerian administrative service, has made a notable contribution to African philology. He has to his credit a grammar and dictionary of Tiv, a book on the principles of Idoma, and a grammar of spoken Hausa. He has completed a revision and enlargement of Bargery's great Hausa dictionary on which he has been at work for twenty years. Among the positions he has held is that of Examiner in Petsian for the Government of India. During war service in Ethiopia he took up the study of Amharic and now has returned thither as Leverhulme Research Fellow to pursue research in that and other languages. He became a member of the Institute in 1934.

\section{Africanized English}

READERs of our October number may have been puzzled to read a reference to 'screwchair' in the report of Professor Ida Ward's lecture on page 209. It should have been 'screw-driver', Africanized as sikudirebba, just as 'spanner' takes the form ifanna and ' hammer' ama. The African showed more imagination who called a bicycle namundelele, ' a spider's web'. Sometimes English words take on strange meanings. Major Abraham heard a man speak of a dunja which he had had with another, i.e. a violent quarrel. This word turned out to be 'danger', prominently displayed as a warning on the railway-line: the association of ideas is obvious when you think of it.

\section{Obituary}

WilLiam Vincent LuCAS, who for thirty-six years was a member of the Universities' Mission to Central Africa - for the last eighteen years Bishop of Masasi-died in Johannesburg on 18 July I945. In the outside world his name is chiefly associated with an experiment in the adaptation of African initiation rites for Christian purposes. His colleague, Lyndon Harries, affirms in the International Review of Missions for October, that he was not very much interested in the study of anthropology for its own sake; but those who worked with him realized that his experiment could never have been effectively introduced but for the Bishop's loving respect for and understanding of the African mind. The experiment was not hastily undertaken, but only after long consideration and patient study. The chapter which he contributed to Essays Catholic and Missionary, and the addresses which he gave to anthropological and other gatherings, revealed his motive and described his procedure. His success was indicated when pagan leaders acknowledged the Christian rite as equivalent to the traditional rite in admitting boys to the tribe and when they showed their preference for it by begging for the inclusion of their own boys. 'The popularity of the rites proves them to be still truly African', says Mr. Harries. Apart from this experiment in applied anthropology, Bishop Lucas's memory will long be cherished for his noble character and complete devotion to the cause he served. 